\title{
Seabird attendance and incidental mortality at shrimp fisheries in Golfo San Jorge, Argentina
}

\author{
Diego González-Zevallos ${ }^{1}$, Pablo Yorio ${ }^{1,2, *}$, Walter S. Svagelj ${ }^{1}$ \\ ${ }^{1}$ Centro Nacional Patagónico (CONICET), Blvd. Brown 2915, U9120ACD, Puerto Madryn, Chubut, Argentina \\ ${ }^{2}$ Wildlife Conservation Society, Amenabar 1595, P 2, Of. 19, C1426AKC, Ciudad de Buenos Aires, Argentina
}

\begin{abstract}
Many seabirds are attracted to trawl vessels to make use of fishery waste, and often this attraction results in increased incidental mortality. We assessed seabird attendance and associated incidental mortality at the Argentine red shrimp Pleoticus muelleri trawl fishery in Golfo San Jorge, Argentina. Information on seabird numbers was gathered in the autumn and winter 2006 and spring 2008, while information on seabird incidental captures was obtained for the period 2005-2007. Eighteen seabird species attended vessels, and the 2 most frequent and abundant seabirds (percent occurrence, median no. haul $\left.{ }^{-1}\right)$ were the kelp gull Larus dominicanus $(>94 \%,<100)$ and blackbrowed albatross Thalassarche melanophrys $(>94 \%,<55)$. Seabird numbers were significantly lower in winter than the other 2 seasons and highest during discarding activities. Species incidentally killed in nets were the Magellanic penguin Spheniscus magellanicus and imperial cormorant Phalacrocorax atriceps, with a mean capture rate of 0.048 birds haul $^{-1}$, and for both species, mortality decreased with distance to the coast. Considering the fishery's fishing effort during each month, the estimated total mortality in the study period was 895 (95\% CI: 572 to 1339) penguins and 172 (95\% CI: 69 to 305 ) cormorants. Over $95 \%$ of the recorded mortality occurred in 2005, the year when the trawling moratorium generally implemented in the area was not enforced. No interactions with warp cables were recorded. Results highlight the relevance of complying with the current moratorium scheme, as adjusting it to the penguin and cormorant breeding seasons may by a potentially effective management tool. The proximity to the coast of the recorded incidental mortalities indicates the need to reevaluate the spatial design of the park and/or the definition of management actions beyond the boundaries of the Marine Protected Area.
\end{abstract}

KEY WORDS: Seabird-fishery interactions - Seabird by-catch - Trawlers - Fishing discards · Patagonia

\section{INTRODUCTION}

The effects of commercial fisheries on seabirds and the marine environment have received growing attention during the last decades. At the global scale, shrimp trawl fisheries are considered as one of the main sources of fishing discards, which may have important effects on marine resources and wildlife (Gillet 2008, Kelleher 2008). Many studies of seabirds at sea have demonstrated their attraction to trawl vessels to make use of fishery waste (Hudson \& Furness 1989, Berghahn \& Rösner 1992, Camphuysen et al.
1995, Oro \& Ruiz 1997, González-Zevallos \& Yorio 2006, Crawford 2007, Wickliffe \& Jodice 2010), and it has been argued that the provision of this supplementary food is an important factor affecting the at-sea distribution, breeding success and population growth of some species (Ryan \& Moloney 1988, Oro et al. 1995, Garthe et al. 1996, Furness 2003, Grémillet et al. 2008). In addition, seabird attraction to fishing vessels can result in an increase in mortality resulting from drowning in fishing gear and/or collisions with warp cables (Weimerskirch et al. 2000, Bull 2007). Recent studies have shown that strikes with warp cables are an impor- 
tant cause of mortalities and serious injuries for seabirds (Sullivan et al. 2006, González-Zevallos et al. 2007, Watkins et al. 2008, Favero et al. 2011).

The commercial fishery targeting the Argentine red shrimp Pleoticus muelleri in Patagonia, Argentina, is one of the country's most important fisheries in terms of economic return (Subsecretaría de Pesca y Acuicultura 2007) and generates large amounts of fishing wastes. Total biomass discarded per year of just Argentine hake Merluccius hubbsi, a demersal species that is not normally available to seabirds that surfacefeed, was estimated between 17200 and $46500 \mathrm{t}$ (Cordo 2005). Preliminary information indicates that several seabirds, including the Endangered blackbrowed albatross Thalassarche melanophrys, the Vulnerable white-chinned petrel Procellaria aequinoctialis, and the Near Threatened sooty shearwater Puffinus griseus and Magellanic penguin Spheniscus magellanicus, use discards made available by shrimp trawlers, but quantitative information is still lacking. In addition, Gandini et al. (1999) have reported that seabirds can be incidentally killed in the Argentine red shrimp fishery.

The shrimp fishery may have a greater potential to affect seabird populations than other fisheries operating in the area (González-Zevallos \& Yorio 2006, González-Zevallos et al. 2007) due to the larger number of vessels and higher discarding rates. In particular, a significant fishing effort is placed in the northern sector of the gulf during the late austral spring and summer (Secretaría de Pesca del Chubut unpubl. data) close to an area with important seabird breeding colonies and which has been recently included in a Marine Park (Yorio 2009). In the present paper, we present information on the association of seabirds with shrimp trawlers in Golfo San Jorge, this fishery's main fishing ground. We determined the species composition of seabirds attending vessels, quantified their relative abundance in relation to the fishing season and stages of fishing operation, and quantified mortality as a result of incidental capture of birds attracted to the vessels to make use of fishery waste. Understanding the main factors affecting mortality rates will help improve the management of the shrimp fishery and minimize its impact on seabird populations.

\section{MATERIALS AND METHODS}

Seabirds and commercial fisheries in the study area. The Golfo San Jorge includes an area of $>32200 \mathrm{~km}^{2}$ (Fig. 1) and is under provincial administration (Chubut Province: $15700 \mathrm{~km}^{2}$ and Santa Cruz Province: $16500 \mathrm{~km}^{2}$ ). Thirteen of the 17 seabirds that breed in Patagonian nests on the islands of the north-
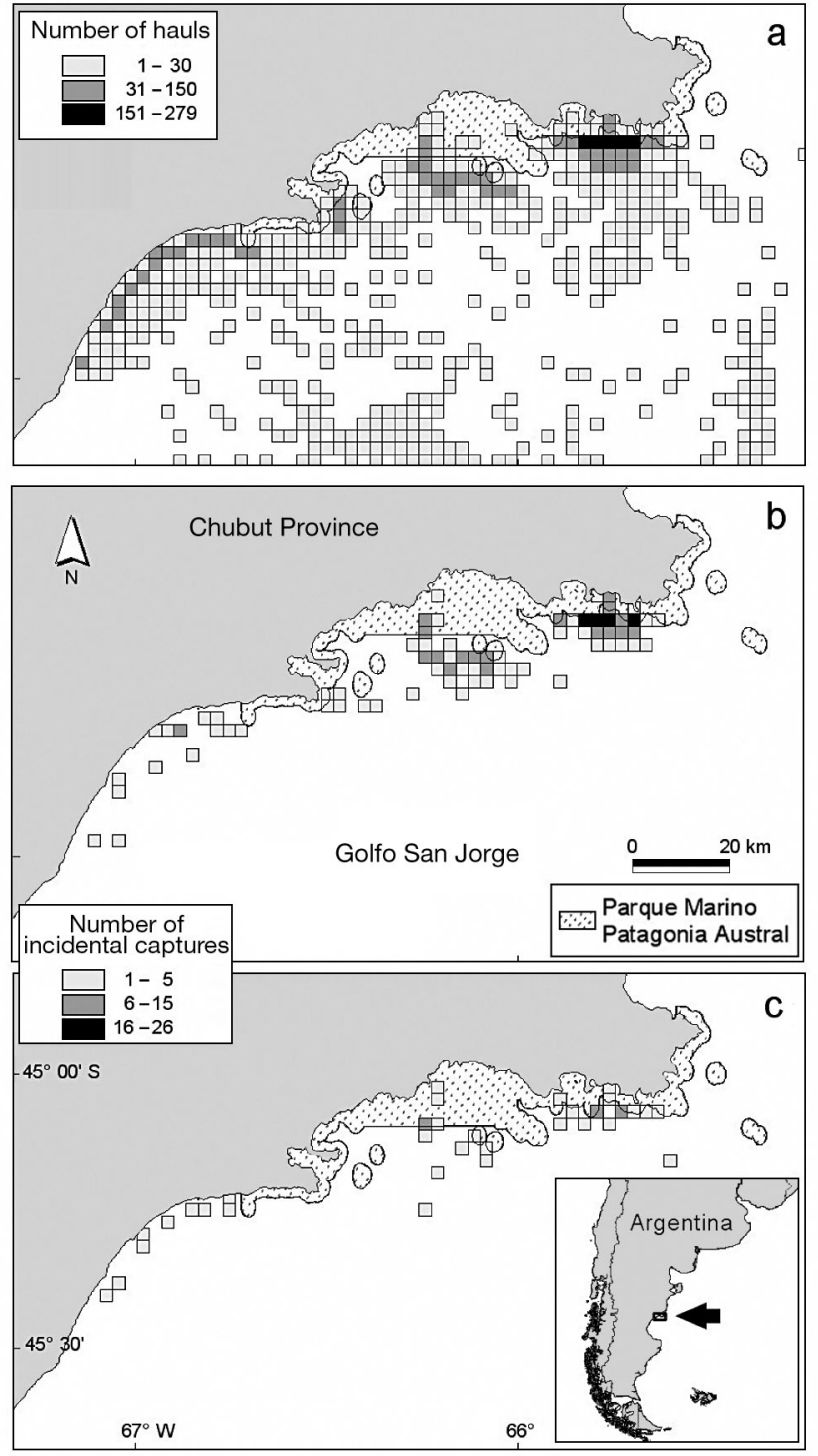

Fig. 1. Golfo San Jorge, Argentina: location of Marine Protected Area 'Parque Marino Patagonia Austral' created in 2008 and spatial distribution of (a) shrimp fishery hauls, (b) Magellanic penguin incidental captures and (c) imperial cormorant incidental captures, between October and March of the 2005-2007 fishing seasons ( $\mathrm{n}=6475$ hauls). Data source: On-board Observer Program of the Chubut Province, Argentina

ern coastal sector of the gulf, and for some species, a significant proportion of the Patagonian population, occur here (Yorio et al. 1998). For example, this sector holds 28 (13300 pairs) and 25\% (240000 pairs) of the imperial cormorants Phalacrocorax atriceps and Magellanic penguins, respectively (Frere et al. 2005, Schiavini et al. 2005). Both species breed in the study area between September and March (Yorio et al. 2001, Punta et al. 2003b). The environmental value of the northern sector of the gulf has resulted in the inclusion 
of a $750 \mathrm{~km}^{2}$ area in 2008, extending from the high tide mark 1 nautical mile (n mile) offshore, in a Marine Park under the joint administration of the National Parks Administration and the Government of the Province of Chubut (Law 26446/08) (Fig. 1). The goals of the Park are to protect representative samples of terrestrial, coastal and marine ecosystems, to ensure the continuity of natural processes and to promote sustainable activities compatible with the conservation of the Park. However, this Marine Park does not yet have a management plan in place.

Commercial fisheries are common in the Golfo San Jorge. Between 70 and 80 double-beam trawlers that target Argentine red shrimp operate in the region from mid-February to November. A fishing moratorium for this fishery was established in 2003, covering the months of December, January and first-half of February, although in the 2005 fishing season, the moratorium was not enforced. Shrimp vessels $(\mathrm{n}=68)$ are (mean \pm SD) $35.4 \pm 5.5 \mathrm{~m}$ long, have $970.6 \pm 297.4 \mathrm{HP}$ engine power, a storage capacity of $81.4 \pm 36.1 \mathrm{t}$, and tow 2 bottom nets $(45 \mathrm{~mm}$ mesh size; $1.2-1.5$ and 30-50 m vertical and horizontal mouth openings, respectively) at 3 knots (On-board Observer Program of Chubut Province unpubl. data). Hauls $(\mathrm{n}=9249)$ are $85.5 \pm 32.9 \mathrm{~min}$ in duration and 79.2 $\pm 18.9 \mathrm{~m}$ deep (Onboard Observer Program of Chubut Province unpubl. data). Trips by trawlers last up to $40 \mathrm{~d}$ (generally 5 to 8 hauls $\mathrm{d}^{-1}$ ). In general, shrimp vessels operate in groups with vessels relatively close to each other. During the study period, mean number of fishing vessels per group was $11.5 \pm 5.83$ (range: 2 to $28, \mathrm{n}=97$ hauls), with an average distance between boats (obtained using the navigation radar) of $2.2 \pm 0.88$ nautical miles (range: 0.7 to $4.4, \mathrm{n}=1405$ measurements) (D. González-Zevallos unpubl. data). The total capture is processed onboard and non-commercial sizes of shrimp and by-catch species are discarded overboard. No offal is discarded at sea. In addition to the doublebeam trawlers, the waters of Golfo San Jorge are used by about 20 high-seas ice trawlers and between 30 to 40 coastal ice trawlers, all targeting Argentine hake (González-Zevallos \& Yorio 2006).

Data collection. Information about seabird assemblages was gathered on board during 105 hauls (23 fishing days) in April and July 2006 ( $\mathrm{n}=52$ and 13, respectively) and in November $2008(\mathrm{n}=40)$. Fishing operations were divided into 3 activities: (1) haulback, lifting of the net to the vessel; (2) discarding, sorting and discarding of fish while towing the net; and (3) towing of the net after fish on board had been classified and no discards were available. In all trips and for each fishing activity, seabirds associated with the vessel were identified to species level and several counts were made at each haul totalling 309 counts
(105 during 'haulback', 105 during 'discarding' and 99 during 'towing'). Counts were made during $15 \mathrm{~min}$ observation periods from the top deck of the vessels, only once half way through each stage of the fishing operation, covering up to 200 m radius. Kelp gulls Larus dominicanus and black-browed albatrosses were identified into adult and young (juvenile and subadult) individuals based on plumage characteristics in the former case (Bo et al. 1995) and plumage and beak coloration in the latter (Onley \& Bartle 1999). Frequency of occurrence was defined as the percentage of hauls in which each species was observed.

Information on incidental captures of seabirds in nets was obtained from the database of the On-board Observer Program of Chubut Province for the 2005-2007 period ( $\mathrm{n}=9249$ hauls, corresponding to the Chubut Jurisdiction), which included species identity, number of birds caught, bathymetry (m), and haul location and duration (min). For each position of incidental captures, we calculated the distance $(\mathrm{km})$ to the nearest coastline using ArcView GIS 3.2 (Environmental Systems Research Institute). Information about contacts (fatal and non-fatal) in warp cables was also obtained from the On-board Observer Program during the same period ( $\mathrm{n}=104$ hauls). In general, discards are discharged on the starboard side of the vessel and flow toward the stern affecting only the corresponding cable. Therefore, observations of bird contacts with the cable at each haul were only made on the corresponding side of the vessel during the time period when fish were discarded.

Statistical analysis. Results concerning seabird attendance at trawlers were analysed using non-parametric statistics. Contrasts were performed using the $Z$-test for non parametric multiple comparisons. Data correlation was analyzed using the Spearman correlation coefficient, $\rho_{\mathrm{s}}$ (Conover 1999). Results are given as the median of the maximum value obtained from the 3 counts, corresponding to the 3 fishing activities, in each haul number and range of individuals (min, max). To test the effects of predictor variables (fishing operation, season, distance to the coast, number of vessels in the vicinity, and sea state) on seabird abundance, we employed generalized linear models with negative binomial error distribution and log link function (McCullagh \& Nelder 1989, Crawley 2007). Fishing operation (haulback, discarding and towing) and season (autumn, winter, and spring) were included as 3level fixed factors. Distance to the coast $(\mathrm{km})$, number of fishing vessels in the vicinity (within a radius of $1.5 \mathrm{n}$ miles) and sea state (in Beaufort scale) were included as continuous variables.

In addition, applying generalized linear models with a binomial family distribution and logit link function, we analyzed the effect of season (spring and summer), 
distance to the coast $(\mathrm{km})$ and haul duration ( $\mathrm{min})$ on the mortality of cormorants and penguins ( $\mathrm{n}=6475$ hauls). Because in most of the cases (93\%) just a single bird died during a haul, our measure of mortality was dichotomical $\left(0=\right.$ no bird died during haul ${ }_{i} 1=$ at least 1 bird died). Winter and autumn seasons were excluded from the analysis because the mortality during these periods was negligible. The bathymetry was excluded from the analysis to be correlated with distance to the coast $\left(\rho_{\mathrm{s}}=0.67, \mathrm{p}<0.001\right)$. Bootstrapping was used to assess confidence intervals (CIs) around the mean mortality rates. This approach makes no assumptions about the statistical distributions of samples (Efron \& Tibshirani 1993). For each set of data, 3000 random re-samplings (with replacement) of the original data set were produced, mean mortality rate was calculated, and the results were then sorted to obtain the $95 \%$ CI of the mean. Total number of hauls made per month by the shrimp fishery (only months when incidental mortality was recorded) were estimated following Lohr (1999):

Estimated hauls $=$ declared captures $\times\left(\frac{\text { observed hauls }}{\text { observed captures }}\right)$

Model selection was based on information-theoretic procedures (Burnham \& Anderson 2002). This method allows model uncertainty to be included in both model evaluation and derivation of parameter estimates (Burnham \& Anderson 2002). Therefore, if model uncertainty existed, inferences were not based on a model or set of models, but relative strength of parameter estimates derived from all models were used (Esler et al. 2001, Svagelj et al. 2009). Models with all possible combinations of predictor variables were considered. This resulted in 32 and 8 candidate models for abundance and mortality analyses, respectively. Akaike's information criterion (AIC) was calculated for each model (Burnham \& Anderson 2002). Model comparisons were made with $\triangle \mathrm{AIC}$, which is the difference between the lowest AIC value (i.e. best of suitable models) and AIC from all other models. The weight of a model $\left(w_{i}\right)$ signifies the relative likelihood that the specific model is the best of the suite of all models. If model uncertainty existed, we evaluated the support for predictor variables summing $w_{i}$ across all models that contained the parameter being considered (parameter likelihood; Burnham \& Anderson 2002). Predictor variables with good support will have high parameter-likelihood values (near 1). Parameter estimates were calculated using model-averaged parameter estimates based on $w_{i}$ for all candidate models. Unconditional variances were used to calculate standard errors (Burnham \& Anderson 2002). To supplement parameter-likelihood evidence of important effects, we also calculated $95 \%$ CI of parameter estimates. Upper and lower confidence limits were calculated by adding or subtracting $2 \mathrm{SE}$, respectively (Burnham \& Anderson 2002). Due to sample size ( $=247$ hauls), our abundance models were evaluated using AIC corrected for small sample size $\left(\mathrm{AIC}_{\mathrm{c}}\right)$. Sample size is lower than that mentioned in Methods $(n=309)$ because predictor variables were not known in all cases.

All statistical analyses were carried out using R software v2.10.1 (R Development Core Team 2009). Values were reported as means $\pm \mathrm{SE}$, except where noted. All tests were 2-tailed, and differences were considered significant at $\mathrm{p}<0.05$.

\section{RESULTS}

\section{Species and abundance of seabirds associated with shrimp vessels}

A total of 18 seabird species were recorded attending vessels in the shrimp trawl fishery operating at Golfo San Jorge during the study period (Table 1). In general, the most frequent and abundant species were the kelp gull and the black-browed albatross, followed by the southern giant petrel Macronectes giganteus, white-chinned petrel, South American tern Sterna hirundinacea, sooty shearwater Puffinus griseus or great shearwater $P$. gravis depending on the season. The rest of the seabirds (11 species) were observed in low numbers and in $<75 \%$ of hauls. Young individuals of kelp gull and black-browed albatross were recorded in 94.3 and $73.3 \%$ of hauls, respectively $(n=105)$. Juvenile individuals represented $24 \%$ of the observed total kelp gulls (autumn: $32.0 \%$, winter: $21.3 \%$, and spring: $20.6 \%$ ), and $27 \%$ of the observed total blackbrowed albatross (autumn: $17.1 \%$, winter: $2.6 \%$, and spring: $41.2 \%$ ).

The number of recorded species was similar among seasons (Kruskal-Wallis $H=4.99$, df $=2, \mathrm{p}=0.073$ ) (Table 1). During autumn, the frequency of occurrence of great and sooty shearwaters was $\sim 95 \%$, and these species had significantly higher abundances than in the other 2 seasons $(H=214.74, \mathrm{df}=2, \mathrm{p}<0.001$; $Z_{\text {contrasts }}$ to $Z_{\text {aut-win }}=83.51, \mathrm{p}<0.001$; to $Z_{\text {aut-spr }}=181.08$, $\mathrm{p}<0.001$; to $Z_{\text {win-spr }}=0.00, \mathrm{p}=0.96$; and $H=130.23$, $\mathrm{df}=2, \mathrm{p}<0.001, Z_{\text {contrasts }}$ to $Z_{\text {aut-win }}=47.32, \mathrm{p}<0.001$; to $Z_{\text {aut-spr }}=112.25, \mathrm{p}<0.001$; to $Z_{\text {win-spr }}=0.07, \mathrm{p}=0.79$, respectively) (Table 1 ).

The best model describing the variation in the abundance of seabirds included fishing operation and season as explanatory variables $\left(w_{i}=0.25\right.$, likelihood ratio test, comparison with null model: $\chi^{2}{ }_{4}=202, \mathrm{p}<0.001$; Tables $2 \& 3$ ) and accounted for $53 \%$ of the variation. There was substantial uncertainty in model selection (Table 3). However, the 2 variables included in the best 
Table 1. Frequency of occurrence $(\% F)$ and abundance (median, range in parentheses) per haul of seabirds attending shrimp trawlers at Golfo San Jorge, Argentina, during autumn (Apr 2006, n= 52), winter (Jul 2006, n = 13) and spring (Nov 2008, $\mathrm{n}=40$ ). $\mathrm{n}=105$ hauls

\begin{tabular}{|c|c|c|c|c|c|c|}
\hline \multirow[t]{2}{*}{ Species } & \multicolumn{2}{|c|}{ Autumn } & \multicolumn{2}{|c|}{ Winter } & \multicolumn{2}{|c|}{ Spring } \\
\hline & $\% F$ & Abundance & $\% F$ & Abundance & $\% F$ & Abundance \\
\hline Kelp gull Larus dominicanus ${ }^{\mathrm{a}}$ & 94.2 & $13.5(0-400)$ & 100 & $40(15-90)$ & 100 & $100(6-450$ \\
\hline Black-browed albatross Thalassarche melanophrys & 94.2 & $42(0-200)$ & 100 & $20(10-55)$ & 100 & $55(4-190)$ \\
\hline Southern giant petrel Macronectes giganteus ${ }^{\mathrm{a}}$ & 90.4 & $4(0-43)$ & 76.9 & $2(0-8)$ & 90 & $2(0-8)$ \\
\hline White-chinned petrel Procellaria aequinoctialis & 63.5 & $4.5(0-50)$ & 100 & $18(2-60)$ & 100 & $11.5(1-60)$ \\
\hline South American tern Sterna hirundinacea ${ }^{\mathrm{a}}$ & 65.4 & $2(0-30)$ & 76.9 & $2(0-3)$ & 80 & $17(0-50)$ \\
\hline Sooty shearwater Puffinus griseus & 94.2 & $20(0-90)$ & 23.07 & $0(0-2)$ & 28.8 & $0(0-2)$ \\
\hline Great shearwater Puffinus gravis & 96.1 & $65(0-200)$ & 0 & 0 & 2.5 & $0(0-2)$ \\
\hline Antarctic skua Catharacta antarctica ${ }^{\mathrm{a}}$ & 28.8 & $0(0-2)$ & 7.7 & $0(0-1)$ & 52.5 & $1(0-2)$ \\
\hline Cape petrel Daption capense & 0 & 0 & 61.5 & $1(0-10)$ & 62.5 & $2(0-10)$ \\
\hline Imperial cormorant Phalacrocorax atriceps ${ }^{\mathrm{a}}$ & 23.1 & $0(0-70)$ & 7.7 & $0(0-2)$ & 37.5 & $0(0-30)$ \\
\hline Wilson's storm-petrel Oceanites oceanicus & 23.1 & $0(0-6)$ & 38.5 & $0(0-3)$ & 25 & $0(0-10)$ \\
\hline Royal albatross Diomedea epomophora & 30.8 & $0(0-6)$ & 38.5 & $0(0-1)$ & 7.5 & $0(0-1)$ \\
\hline Magellanic penguin Spheniscus magellanicus ${ }^{\mathrm{a}}$ & 1.9 & $0(0-2)$ & 0 & 0 & 12.5 & $0(0-40)$ \\
\hline Royal tern Sterna maxima ${ }^{a}$ & 3.8 & $0(0-2)$ & 15.4 & $0(0-3)$ & 0 & 0 \\
\hline Grey-headed albatross Diomedea chrysostoma & 3.8 & $0(0-1)$ & 7.7 & $0(0-2)$ & 0 & 0 \\
\hline Sheathbill Chionis alba & 5.8 & $0(0-1)$ & 0 & 0 & 0 & 0 \\
\hline Cayenne tern Thalasseus sandvicencis eurygnatha ${ }^{a}$ & 1.9 & $0(0-1)$ & 0 & 0 & 2.5 & $0(0-10)$ \\
\hline Antarctic fulmar Fulmarus glacialoides & 0 & 0 & 15.4 & $0(0-1)$ & 0 & 0 \\
\hline Median no. species haul ${ }^{-1}$ & \multicolumn{2}{|c|}{$7(3-10)$} & \multicolumn{2}{|c|}{$7(4-9)$} & \multicolumn{2}{|c|}{$7(3-10)$} \\
\hline Median no. birds haul ${ }^{-1}$ & \multicolumn{2}{|c|}{$198(54-576)$} & \multicolumn{2}{|c|}{$107(56-151)$} & \multicolumn{2}{|c|}{$199(15-712)$} \\
\hline
\end{tabular}

Table 2. Median abundance (range) of individuals (ind.) haul ${ }^{-1}$ during different stages of the fishing operation for the more frequent $(>75 \%)$ seabird species attending shrimp trawlers at Golfo San Jorge, Argentina. $\mathrm{n}=$ no. of hauls

\begin{tabular}{|lccc|}
\hline Species & $\begin{array}{c}\text { Haulback } \\
(\mathrm{n}=105)\end{array}$ & $\begin{array}{c}\text { Discarding } \\
(\mathrm{n}=105)\end{array}$ & $\begin{array}{c}\text { Towing } \\
(\mathrm{n}=99)\end{array}$ \\
\hline Kelp gull & $29(0-305)$ & $50(0-450)$ & $10(0-70)$ \\
Black-browed albatross & $16(0-130)$ & $40(0-200)$ & $5(0-35)$ \\
Southern giant petrel & $1(0-28)$ & $2(0-43)$ & $2(0-6)$ \\
White-chinned petrel & $4(0-60)$ & $10(0-50)$ & $1(0-20)$ \\
South American tern & $1(0-50)$ & $2(0-50)$ & $0(0-14)$ \\
Sooty shearwater & $0(0-40)$ & $0(0-90)$ & $0(0-30)$ \\
$\begin{array}{l}\text { Great shearwater } \\
\text { Total no. of ind. }\end{array}$ & $0(0-80)$ & $0(0-200)$ & $0(0-90)$ \\
(all 18 species) & $81(0-456)$ & $178(10-710)$ & $37(0-194)$ \\
\hline
\end{tabular}

model were important predictors of seabird abundance as both had the highest likelihood parameter values (Table 4), being included in all models with $\Delta \mathrm{AIC}_{\mathrm{C}} \leq 2$ (Table 3). The seabird abundance was highest during discarding and lowest during towing (178, 81 and 37 birds for discarding, haulback and towing, respectively; Table 4). In the other hand, seabird abundance during winter was lower than for autumn and spring (Tables 1 \& 4). As indicated by low parameter likelihood values and CI including zero, other explanatory variables (distance to the coast, number of vessels in the vicinity and sea state) were not related to seabird abundance (Table 4).

\section{Seabird incidental mortality}

A total of 441 individuals (363 Magellanic penguins and 78 imperial cormorants) were caught during the 2005-2007 period. These 2 species were incidentally caught in nets, with rates that varied between months (Table 5) and a mean capture rate of 0.048 birds haul ${ }^{-1}$ ( $\mathrm{n}=9249$ hauls). Seabird incidental captures occurred close to shore, at a mean distance of $7.62 \pm 6.93 \mathrm{~km}$ (range: 0.7 to 90.8 ) for Magellanic penguins and $5.4 \pm 4.22 \mathrm{~km}$ (range: 1 to 20.8) for imperial cormorants (Fig. 1). No birds were killed during the winter months, and the highest number of birds killed was recorded in December 2005 (Table 5). Considering the total number of hauls made by the whole fishing fleet during each month of the study (Table 5), the estimated total seabird mortality for 2005-2007 was 1067 birds (95\% CI: 641 to 1644) (895 Magellanic penguins and 172 imperial cormorants; 95\% CI: 572 to 1339 and 69 to 305, respectively). It should be noted that given the uncertainty associated with the mortality estimates, these should be considered just an indication of the actual figures of birds killed in nets. No contacts (fatal and non-fatal) between seabirds and warp cables were recorded ( $\mathrm{n}=104$ hauls). During 2005, the proportion of hauls made within the area included in the Marine Park since 2008 was $10.6 \%$ ( $\mathrm{n}=$ 
5330 hauls), while during 2006 and 2007, the proportion was only 0.22 and $0.12 \%$, respectively $(\mathrm{n}=2293$ and 1626 hauls, respectively). During 2005, the mortality rate was significantly higher within than outside the area currently included in the Marine Park (0.13 and 0.07 birds haul ${ }^{-1}$, respectively, Mann-Whitney $U=$ $18179, \mathrm{df}=1, \mathrm{p}<0.001$ ).

The best model describing the variation in Magellanic penguin mortality included season, distance to the coast and haul duration as explanatory variables and accounted for $7 \%$ of the variation $\left(w_{i}=0.998\right.$, like-

Table 3. Generalized linear models explaining the variation in seabird abundance. The null model, global model, and models with strong support $\left(\Delta \mathrm{AIC}_{\mathrm{c}} \leq 2\right)$ are provided, and listed in decreasing order of importance. FIO = fishing operation $(3$ levels: haulback, discarding and towing), SEA = season (3 levels: autumn, winter and spring), DIS = distance to coast, $\mathrm{VES}=$ number of vessels in the vicinity (within 1.5 nautical miles radius), $\mathrm{SST}=$ sea state (Beaufort scale), $\mathrm{AIC}_{c}$ : corrected Akaike's information criterion, $w_{i}$ : $\mathrm{AIC}_{\mathrm{c}}$ weights

\begin{tabular}{|lcccc|}
\hline $\begin{array}{l}\text { Explanatory } \\
\text { variable }\end{array}$ & $\begin{array}{c}\text { No. of } \\
\text { parameters }\end{array}$ & $\mathrm{AIC}_{\mathrm{c}}$ & $\Delta \mathrm{AIC}_{\mathrm{c}}$ & $W_{i}$ \\
\hline FIO SEA & 6 & 2653.9 & 0.0 & 0.250 \\
FIO SEA SST & 7 & 2654.3 & 0.4 & 0.200 \\
FIO SEA VES SST & 8 & 2655.0 & 1.2 & 0.139 \\
FIO SEA VES & 7 & 2655.4 & 1.5 & 0.116 \\
FIO SEA DIS & 7 & 2655.6 & 1.7 & 0.107 \\
Global model & 9 & 2656.8 & 3.0 & 0.057 \\
Null model & 2 & 2847.6 & 193.8 & 0.000 \\
\hline
\end{tabular}

Table 4. Parameter estimates $( \pm \mathrm{SE})$ from generalized linear models describing variation in seabird abundance. Parameter likelihoods are corrected Akaike's information criterion weights $\left(w_{i}\right)$ summed across all models that contained that parameter and are indicative of the importance of the variable. Parameter estimates are weighted averages (using $\left.W_{i}\right)$ from all models, and SE are calculated from all candidate models using unconditional variances. Upper and lower confidence interval (CI) limits $(95 \%)$ were calculated adding or subtracting 2 SE, respectively. Explanatory variables with CI excluding zero are in bold

\begin{tabular}{|c|c|c|c|c|}
\hline \multirow{2}{*}{$\begin{array}{l}\text { Explanatory } \\
\text { variable }\end{array}$} & \multirow{2}{*}{$\begin{array}{l}\text { Parameter } \\
\text { likelihood }\end{array}$} & \multirow{2}{*}{$\begin{array}{c}\text { Parameter } \\
\text { estimate } \pm \mathrm{SE}\end{array}$} & \multicolumn{2}{|c|}{$\mathrm{CI}$} \\
\hline & & & Lower & Upper \\
\hline Intercept & & $4.78 \pm 0.15$ & 4.48 & 5.08 \\
\hline $\begin{array}{l}\text { Fishing operation } \\
\text { (discarding) }^{\mathrm{a}}\end{array}$ & 1.000 & $0.70 \pm 0.09$ & 0.52 & 0.88 \\
\hline $\begin{array}{l}\text { Fishing operation } \\
\text { (towing) }^{\mathrm{a}}\end{array}$ & 1.000 & $-0.82 \pm 0.09$ & -1.00 & -0.63 \\
\hline Season (winter) ${ }^{b}$ & 1.000 & $-0.63 \pm 0.11$ & -0.86 & -0.40 \\
\hline Season (spring) ${ }^{b}$ & 1.000 & $0.05 \pm 0.10$ & -0.15 & 0.24 \\
\hline Distance to the coast & 0.295 & $-0.001 \pm 0.001$ & -0.004 & 0.002 \\
\hline Number of vessels & 0.361 & $-0.010 \pm 0.010$ & -0.031 & 0.011 \\
\hline Sea state & 0.478 & $-0.057 \pm 0.041$ & -0.138 & 0.025 \\
\hline
\end{tabular}

lihood ratio test, comparison with null model: $\chi^{2}{ }_{3}=187$, $\mathrm{p}<0.001$; Table 6). Penguin mortality during summer was lower than that for spring (summer: 164 birds in 4346 hauls, spring: 209 birds in 2370 hauls; $\chi^{2}{ }_{1}=144$, $\mathrm{p}<0.001)$. Penguin mortality decreased with the distance to the coast $\left(\beta=-0.052 \pm 0.007 ; \chi^{2}{ }_{1}=98.5, \mathrm{p}<\right.$ 0.001 ; Fig. 2) and increased with haul duration $(\beta=$ $\left.0.007 \pm 0.002 ; \chi^{2}{ }_{1}=14.0, \mathrm{p}<0.001\right)$.

The best model describing the imperial cormorant mortality included season and distance to the coast as explanatory variables $\left(w_{i}=0.576, \chi^{2}{ }_{2}=23.1, \mathrm{p}<0.001\right.$; Table 6). However, this model accounted only for $3 \%$ of the variation. Cormorant mortality during spring was lower than that for summer (spring: 10 birds in 2370 hauls, summer: 70 birds in 4346 hauls; $\chi^{2}{ }_{1}=8.8$, $\mathrm{p}<0.005)$. In addition, cormorant mortality decreased with the distance to the coast $\left(\beta=-0.029 \pm 0.017 ; \chi^{2}{ }_{1}=\right.$ 5.0, p $<0.05$; Fig. 3). Haul duration was unrelated to cormorant mortality $\left(\chi^{2}{ }_{1}=0.1, p=0.76\right)$.

\section{DISCUSSION}

A variety of seabirds, including divers and surface feeders, were attracted to double-beam shrimp trawlers operating in the Chubut Jurisdiction of Golfo San Jorge. These included species that breed along nearby coasts of the gulf and species from other regions (i.e. Malvinas/Falkland Islands, South Georgia, and Antarctica) that may be foraging in these waters during their breeding season or winter migration. The kelp gull and the black-browed albatross were the most commonly observed species throughout the year while shearwaters were common during autumn. The increase in frequency of occurrence and abundance of sooty and great shearwaters during the autumn agrees with their transequatorial migration and presence along the Argentine coast from the late austral summer throughout the autumn (Warham 1996). A similar composition in seabird assemblages was observed for the hake trawl fishery operating in the same area (González-Zevallos \& Yorio 2006), where the kelp gull and black-browed albatross were also the most frequent and abundant species followed by the white-chinned petrel. As expected, seabird numbers varied depending on the season and the fishing operation and were higher during discarding, when food availability was higher. Seabirds, particularly kelp gulls, were often seen moving among vessels which generally operate in groups and relatively close to each other, suggesting that careful consideration should be paid 
Table 5. Spheniscus magellanicus and Phalacrocorax atriceps. Incidental captures and estimated mortality of Magellanic penguins and imperial cormorants in the shrimp fishery operating at Golfo San Jorge, Argentina, between $2005-2007$ ( $\mathrm{n}=9249$ hauls). References: estimated hauls (Est.), observed hauls (Obs.), no. of individuals killed (NoIK), mortality rate (MR), estimated total mortality (ETM), and confidence interval (CI). Data source: On-board Observer Program of the Chubut Province, Argentina

\begin{tabular}{|c|c|c|c|c|c|c|c|c|c|c|c|}
\hline & Feb & Mar & Apr & May & Jun & Jul & Aug & Sep & Oct & Nov & Dec \\
\hline \multicolumn{12}{|l|}{2005} \\
\hline Est. & 2772 & 5084 & 9842 & - & - & - & - & - & 433 & 596 & 2115 \\
\hline Obs. & 2772 & 773 & 114 & - & - & - & - & - & 423 & 325 & 923 \\
\hline \multicolumn{12}{|c|}{ Magellanic penguin } \\
\hline NoIK & 128 & 33 & 1 & - & - & - & - & - & 0 & 55 & 140 \\
\hline MR & 0.046 & 0.043 & 0.009 & - & - & - & - & - & 0 & 0.169 & 0.152 \\
\hline ETM & 128 & 217 & 86 & - & - & - & - & - & - & 101 & 321 \\
\hline CI & $106-152$ & 116-338 & $0-256$ & - & - & - & - & - & - & $75-125$ & $273-370$ \\
\hline \multicolumn{12}{|c|}{ Imperial cormorant } \\
\hline NoIK & 52 & 8 & 0 & - & - & - & - & - & 0 & 7 & 0 \\
\hline MR & 0.019 & 0.010 & 0 & - & - & - & - & - & 0 & 0.021 & 0 \\
\hline ETM & 52 & 53 & - & - & - & - & - & - & - & 13 & - \\
\hline CI & $38-66$ & $20-89$ & - & - & - & - & - & - & - & $5-21$ & - \\
\hline \multicolumn{12}{|l|}{2006} \\
\hline Est. & - & - & 1345 & 2821 & - & - & - & - & - & - & - \\
\hline Obs. & - & - & 511 & 537 & 354 & 215 & 48 & 272 & 356 & - & - \\
\hline \multicolumn{12}{|c|}{ Magellanic penguin } \\
\hline NoIK & - & - & 3 & 0 & 0 & 0 & 0 & 0 & 0 & - & - \\
\hline MR & - & - & 0.006 & 0 & 0 & 0 & 0 & 0 & 0 & - & - \\
\hline ETM & - & - & 8 & - & - & - & - & - & - & - & - \\
\hline $\mathrm{CI}$ & - & - & $2-16$ & - & - & - & - & - & - & - & - \\
\hline \multicolumn{12}{|c|}{ Imperial cormorant } \\
\hline NoIK & - & - & 6 & 1 & 0 & 0 & 0 & 0 & 0 & - & - \\
\hline MR & - & - & 0.012 & 0.002 & 0 & 0 & 0 & 0 & 0 & - & - \\
\hline ETM & - & - & 16 & 5 & - & - & - & - & - & - & - \\
\hline $\mathrm{CI}$ & - & - & $6-27$ & $0-16$ & - & - & - & - & - & - & - \\
\hline \multicolumn{12}{|l|}{2007} \\
\hline Est. & - & 7473 & - & - & - & - & - & - & 1356 & - & - \\
\hline Obs. & - & 646 & 44 & 42 & 24 & 71 & 320 & 222 & 257 & - & - \\
\hline \multicolumn{12}{|c|}{ Magellanic penguin } \\
\hline NoIK & - & 3 & 0 & 0 & 0 & 0 & 0 & 0 & 0 & - & - \\
\hline MR & - & 0.005 & 0 & 0 & 0 & 0 & 0 & 0 & 0 & - & - \\
\hline ETM & - & 34 & - & - & - & - & - & - & - & - & - \\
\hline $\mathrm{CI}$ & - & $0-82$ & - & - & - & - & - & - & - & - & - \\
\hline \multicolumn{12}{|c|}{ Imperial cormorant } \\
\hline NoIK & - & 2 & 0 & 0 & 0 & 0 & 0 & 0 & 2 & - & - \\
\hline MR & - & 0.003 & 0 & 0 & 0 & 0 & 0 & 0 & 0.008 & - & - \\
\hline ETM & - & 23 & - & - & - & - & - & - & 10 & - & - \\
\hline $\mathrm{CI}$ & - & $0-55$ & - & - & - & - & - & - & $0-31$ & - & - \\
\hline
\end{tabular}

when extrapolating these results to the whole fishery to estimate the total number of associated seabirds.

Shrimp fisheries are one of the main sources of fishing discards at the global scale (Kelleher 2008). At Golfo San Jorge, the shrimp fishery produces significant amounts of discards (Cordo 2005) that are largely composed of Argentine hake, a demersal fish that is not normally available to surface feeders. Fishery waste provided to seabirds by shrimp trawlers complements that resulting from the hake fishery's activities (González-Zevallos \& Yorio 2006) and may be particularly important to seabird populations during the winter months when, in general, hake trawlers do not operate. The use of this abundant and predictable food source might have important effects on some of the seabirds that breed at Golfo San Jorge, as it could contribute to increased breeding success, improved body condition and/or individual survival, particularly of young birds. Kelp gulls, for example, have shown a significant population increase in the study area (Yorio et al. 2005). The present study indicates that kelp gulls, including young individuals, attend trawlers and apparently consume discards throughout the year, and preliminary studies at breeding colonies in Golfo San Jorge indicate that Argentine hake, the main species discarded by fisheries operating in the gulf, is an important component of the diet of incubating adults and chicks (D. González-Zevallos \& P. Yorio unpubl. 
Table 6. Generalized linear models explaining variation in Magellanic penguin and imperial cormorant mortality. Null model and models with strong support $\left(\Delta \mathrm{AIC}_{\mathrm{c}} \leq 2\right)$ are provided and listed in decreasing order of importance. SEA = season (2 levels: autumn and spring), DIS = distance to coast, DUR $=$ haul duration $(\mathrm{min})$. AIC $\left(\right.$ AIC $\left._{\mathrm{c}}\right)$ : (corrected) Akaike's information criterion, $w_{i}$ : AIC weights

\begin{tabular}{|lcrrr|}
\hline $\begin{array}{l}\text { Explanatory } \\
\text { model }\end{array}$ & $\begin{array}{c}\text { No. of } \\
\text { parameters }\end{array}$ & AIC & $\Delta$ AIC & $w_{i}$ \\
\hline Magellanic penguin & & & & \\
$\begin{array}{l}\text { SEA DIS DUR } \\
\text { SEA DIS }\end{array}$ & 4 & 2394.0 & 0.0 & 0.998 \\
SEA DUR & 3 & 2406.0 & 12.0 & 0.002 \\
SEA & 3 & 2490.5 & 96.5 & 0.000 \\
DIS DUR & 2 & 2497.9 & 103.9 & 0.000 \\
DIS & 3 & 2536.3 & 142.3 & 0.000 \\
DUR & 2 & 2545.8 & 151.8 & 0.000 \\
Null model & 2 & 2566.1 & 172.1 & 0.000 \\
Imperial cormorant & 1 & 2574.6 & 180.6 & 0.000 \\
SEA DIS & & & & \\
SEA DIS DUR & 3 & 797.3 & 0.0 & 0.576 \\
SEA & 4 & 799.2 & 1.9 & 0.222 \\
SEA DUR & 2 & 800.3 & 3.0 & 0.127 \\
DIS & 3 & 802.2 & 5.0 & 0.048 \\
DIS DUR & 2 & 804.0 & 6.8 & 0.020 \\
Null model & 3 & 805.9 & 8.7 & 0.008 \\
DUR & 1 & 816.4 & 19.1 & 0.000 \\
& 2 & 818.3 & 21.0 & 0.000 \\
\hline
\end{tabular}

data). Similarly, it has been argued that the use of discards provided by trawlers operating at Golfo San Jorge and the Patagonian shelf may be one of the factors determining the increase of southern giant petrel populations breeding in the area (Quintana et al. 2006, Copello \& Quintana 2009). Southern giant petrels breeding at Golfo San Jorge show a strong association to all trawl fisheries operating in the area (Copello \& Quintana 2009) and regularly include discards in their diet (Copello \& Quintana 2003, Copello et al. 2008). Although Magellanic penguins and imperial cormorants have been recorded taking advantage of discards at this and other fisheries operating at Golfo San Jorge, they do so in relatively low frequencies and/or numbers (Yorio \& Caille 1999, González-Zevallos \& Yorio 2006); thus, it is unlikely that their populations benefit much from this supplementary food source. Moreover, studies on imperial cormorant diet at Golfo San Jorge suggest that Argentine hake is a prey of secondary importance (Punta et al. 2003a, Bulgarella et al. 2008), except for individuals from colonies located in the northern sector of the study area (Yorio et al. 2010). Diet composition of Magellanic penguins at Golfo San Jorge is unknown, but available information from other locations in Chubut province indicates that they mainly feed on anchovy Engraulis anchoita, with the contribution of Argentine hake in some colonies (Frere et al. 1996, Scolaro et al. 1999). Future studies should analyze in greater detail the dependence on discards of seabirds breeding within the gulf.

The attraction to shrimp vessels to make use of discards resulted in seabird incidental mortality, although it was restricted to the Magellanic penguin and imperial cormorant, both divers. Cormorants and penguins often dive to take prey directly from the net during haulback, increasing their chances of becoming entangled (González-Zevallos \& Yorio 2006). The mortality of these 2 species, particularly the Magellanic penguin, has been previously reported in shrimp vessels at Golfo San Jorge by Gandini et al. (1999) (an estimated 650 Magellanic penguins per summer). The results of

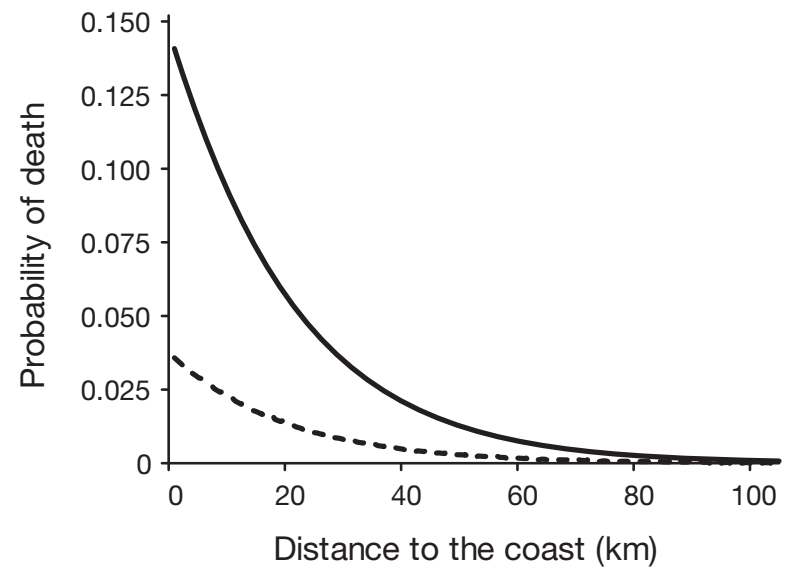

Fig. 2. Spheniscus magellanicus. Relationship between probability of death and distance to coast for Magellanic penguins in spring (continuous line) and summer (dashed line). Adjusted functions were obtained from a generalized linear model with binomial family distribution and logit link function (see 'Materials and methods: Statistical analysis')

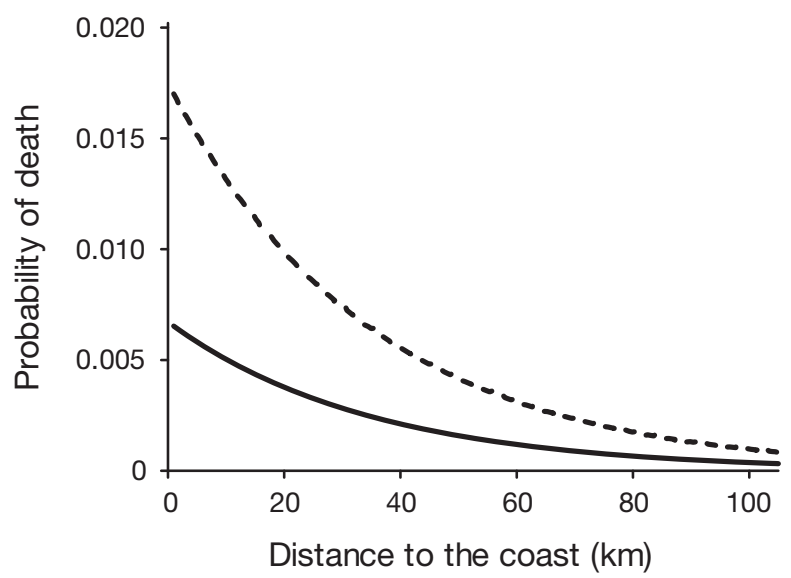

Fig. 3. Phalacrocorax atriceps. Relationship between probability of death and distance to coast for imperial cormorants in spring (continuous line) and summer (dashed line). See Fig. 2 for details on functions 
the present study show that season, distance to the coast and haul duration were variables associated with Magellanic penguin mortality, while imperial cormorant mortality was more related to season and distance to coast. Penguins and cormorants were killed mostly in fishing areas located close to their colonies, in waters currently protected by the Marine Park, indicating the potential of spatial management to reduce the impact of fisheries on seabird breeding populations. No incidental captures were observed during the winter months, probably because part of the Magellanic penguin and imperial cormorant populations migrate or disperse north outside the gulf during their non-breeding season (Stokes et al. 1998, Punta et al. 2003a). In addition, during the winter months, vessels operate further offshore and partly within the jurisdictional waters of the Santa Cruz Province (Secretaría de Pesca de la Provincia de Chubut unpubl. data). Haul duration was also related to penguin mortality, very likely because more birds are attracted during longer hauls, increasing the chances of a bird being incidentally caught in the net. Incidental mortality of the same 2 species was recorded at hake trawlers operating in the same area (González-Zevallos \& Yorio 2006); thus, evaluations on the effects of the activity on their populations should consider the additive impact of both fisheries. Unfortunately, the effects of the estimated incidental mortality in shrimp fisheries on the population dynamics of penguins and cormorants breeding at Golfo San Jorge is still unknown, but mortality of adult individuals should not be underestimated given the life-history traits of seabirds (Furness \& Monaghan 1987, Saether \& Bakke 2000). In contrast to what was observed in hake trawlers, where black-browed albatross and kelp gulls are killed by warp cables (González-Zevallos et al. 2007), no interactions with cables were recorded at shrimp trawlers. In general, outriggers stretch about $6 \mathrm{~m}$ off the side of the vessel, and thus, cables enter the water outside of the trail of discards that flow to the stern of the boat, reducing the chances of bird contacts. This also shows that negative effects of trawls fisheries on seabirds may be dependent on fishing gear characteristics.

Over $95 \%$ of the recorded mortality occurred in 2005, the year when the trawling moratorium generally implemented in the area was not enforced, and $\sim 60 \%$ of the fishery's catch occurred within the period when it is generally implemented, resulting in a high number of birds killed during the months of December and February (January was not sampled). This suggests that birds may be more vulnerable to incidental mortality during such months, which coincides with the chick stage of both penguins and cormorants. Despite possible variability between years in mortality rate due to other factors, the lack of fishing activity during the height of the penguins' and cormorants' breeding seasons due to the enforcement of the moratorium in 2006 and 2007, possibly contributed to the lower observed mortality in comparison to 2005. It is interesting to note that the mortality of Magellanic penguins at shrimp vessels reported by Gandini et al. (1999) for the years 1995 to 1997, before the establishment of the trawling moratorium, occurred only between mid-December and mid-March.

Results show the potential of shrimp fisheries of affecting penguin and cormorant populations through incidental mortality, although it is likely that total mortality would be in general lower than that presented in this study as shrimp fisheries do not normally operate during almost 3 mo of these seabirds' breeding cycle. Results also suggest that the lack of activity of the shrimp fishery during the height of the seabird breeding period as a result of the moratorium may be a key determinant of the lower incidental mortality observed in 2006 and 2007. This clearly indicates that the established fishing moratorium (December, January and first-half of February), designed to minimize the negative effects of fishing on Argentine hake stocks may have also reduced the impact on penguin and cormorant populations breeding in the area.

In summary, fishing waste discarded overboard by the shrimp fishery operating in Golfo San Jorge attracted several seabirds, which may lead to negative consequences if they become dependent on the discards or are injured and killed in the process of taking advantage of this supplementary food source. Results highlight the relevance of complying with the current moratorium scheme, as adjusting it to the penguin and cormorant breeding seasons may by a potentially effective management tool. In addition, the proximity to the coast of the recorded incidental mortalities indicates the need to re-evaluate the spatial design of the park and/or the definition of management actions beyond the boundaries of the Marine Protected Area (Yorio 2009). Finally, given the fishing effort, discard rates and subsequent potential effects of the shrimp fishery in the study area, seabird populations should be considered important components when developing and implementing management guidelines for this fishery.

Acknowledgements. We thank Centro Nacional Patagónico (CONICET) for institutional support, Secretaría de Pesca de la Provincia de Chubut for logistical support and providing data from the On-board Observer Program, and Wildlife Conservation Society for financial support. Special thanks to M. E. Góngora, J. Lancelotti, A. Gatto, P. Dell Arciprete and 5 anonymous reviewers for their constructive comments on earlier versions of the manuscript. Thanks to the captains and crews of the shrimp trawlers for facilitating the work on board. 


\section{LITERATURE CITED}

Berghahn R, Rösner HU (1992) A method to quantify feeding of seabirds on discard from the shrimp fishery in the north sea. Neth J Sea Res 28:347-350

Bo NA, Darrieu CA, Camperi AR (1995) Aves Charadriiformes: Laridae y Rynchopidae. In: Fauna de agua dulce de la República Argentina, Vol 3, Fascicle 4a. Profadu (CONICET), La Plata, p 1-47

Bulgarella M, Cella Pizarro L, Quintana F, Sapoznikow A, Gosztonyi AE, Kuba L (2008) Diet of imperial cormorants (Phalacrocorax atriceps) and rock shags (P. magellanicus) breeding sympatrically in Patagonia, Argentina. Ornitol Neotrop 19:553-563

Bull LS (2007) Reducing seabird bycatch in longline, trawl and gillnet fisheries. Fish Fish 8:31-56

Burnham KP, Anderson DR (2002) Model selection and multimodel inference: a practical information-theoretic approach. Springer-Verlag, New York, NY

Camphuysen CJ, Calvo B, Durinck J, Ensor K and others (1995) Consumption of discards by seabirds in the North Sea. Final report EC DG XIV research contract BIOECO/93/10, Netherlands Institute for Sea Research, Texel

Conover WJ (1999) Practical nonparametric statistics. John Wiley \& Sons, New York, NY

Copello S, Quintana F (2003) Marine debris ingestion by southern giant petrels and its potential relationships with fisheries in the Southern Atlantic Ocean. Mar Pollut Bull 46:1513-1515

Copello S, Quintana F (2009) Spatio-temporal overlap between the at-sea distribution of southern giant petrels and fisheries at the Patagonian Shelf. Polar Biol 32:1211-1220

Copello S, Quintana F, Perez F (2008) The diet of the southern giant petrel in Patagonia: fishery-related items and natural prey. Endang Species Res 6:15-23

Cordo H (2005) Evaluación del estado del efectivo sur de $41^{\circ} \mathrm{S}$ de la Merluza (Merluccius hubbsi) y estimación de la captura biológicamente aceptable correspondiente al año 2005. Instituto Nacional de Investigación y Desarrollo Pesquero (INIDEP), Mar del Plata

Crawford RJM (2007) Food, fishing and seabirds in the Benguela upwelling system. J Ornithol 148(Suppl 2): 253-260

Crawley MJ (2007) The R book. John Wiley \& Sons, West Sussex

Efron B, Tibshirani RJ (1993) An introduction to the bootstrap. Chapman \& Hall, London

Esler D, Grand JB, Afton AD (2001) Intraspecific variation in nutrient reserve use during clutch formation by Lesser Scaup. Condor 103:810-820

Favero M, Blanco G, García G, Copello S and others (2011) Seabird mortality associated with ice trawlers in the Patagonian shelf: effect of discards on the occurrence of interactions with fishing gear. Anim Conserv 14:131-139

Frere E, Gandini PA, Lichtschein V (1996) Variación latitudinal en la dieta del pingüino de magallanes (Spheniscus magellanicus) en la costa patagónica, Argentina. Ornitol Neotrop 7:35-41

Frere E, Quintana F, Gandini P (2005) Cormoranes de la costa patagónica: estado poblacional, ecología y conservación. Hornero 20:35-52

Furness RW (2003) Impacts of fisheries on seabird communities. Sci Mar 67(Suppl 2):33-45

Furness RW, Monaghan P (1987) Seabird ecology. Blackie, Glasgow

Gandini PA, Frere E, Pettovello AD, Cedrola PV (1999) Inter- action between Magellanic penguins and shrimp fisheries in Patagonia, Argentina. Condor 101:783-789

Garthe S, Camphuysen K, Furness R (1996) Amounts of discards by commercial fisheries and their significance as food for seabirds in the North Sea. Mar Ecol Prog Ser 136: $1-11$

Gillet R (2008) Global study of shrimp fisheries. FAO, Rome

González-Zevallos D, Yorio P (2006) Seabird use of discards and incidental captures at the Argentine hake trawl fishery in the Golfo San Jorge, Argentina. Mar Ecol Prog Ser 316:175-183

González-Zevallos D, Yorio P, Caille G (2007) Seabird mortality at trawler warp cables and a proposed mitigation measure: a case of study in Golfo San Jorge, Patagonia, Argentina. Biol Conserv 136:108-116

Grémillet D, Pichegru L, Kuntz G, Woakes AG, Wilkinson S, Crawford RJM, Ryan PG (2008) A junk-food hypothesis for gannets feeding on fishery waste. Proc R Soc Lond B Biol Sci 275:1149-1156

Hudson AV, Furness RW (1989) The behaviour of seabirds foraging at fishing boats around Shetland. Ibis 131:225-237

Kelleher K (2008) Discards in the world's marine fisheries: an update. FAO, Rome

Lohr SL (1999) Sampling: design and analysis. Duxbury Press, Pacific Grove, CA

McCullagh P, Nelder JA (1989) Generalized linear models. Chapman \& Hall, New York, NY

Onley D, Bartle S (1999) Identification of seabirds of the Southern Ocean. A guide for scientific observers aboard fishing vessels. New Zealand Museum Te Papa Tongarewa, Wellington

Oro D, Ruiz X (1997) Exploitation of trawler discards by breeding seabirds in the north-western Mediterranean: differences between the Ebro Delta and the Balearic Islands areas. Mark Sci 54:695-707

> Oro D, Bosch M, Ruiz X (1995) Effects of a trawler moratorium on the breeding success of the yellow-legged gull Larus cachinnans. Ibis 137:547-549

> Punta G, Yorio P, Herrera G (2003a) Temporal patterns in the diet and food partitioning in imperial cormorants (Phalacrocorax atriceps) and rock shags (P. magellanicus) breeding at Bahía Bustamante, Argentina. Wilson Bull 115:307-315

Punta G, Yorio P, Herrera G, Saravia J (2003b) Biología reproductiva de los Cormoranes Imperial (Phalacrocorax atriceps) y Cuello Negro (P. Magellanicus) en el Golfo San Jorge, Chubut, Argentina. Hornero 18:103-111

> Quintana F, Punta G, Copello S, Yorio P (2006) Population status and trends of Southern Giant Petrels (Macronectes giganteus) breeding in North Patagonia, Argentina. Polar Biol 30:53-59

R Development Core Team (2009) R: a language and environment for statistical computing. R Foundation for Statistical Computing, Vienna, available at www.R-project.org

Ryan PG, Moloney CL (1988) Effect of trawling on bird and seal distributions in the southern Benguela region. Mar Ecol Prog Ser 45:1-11

Saether BE, Bakke $\varnothing(2000)$ Avian life history variation and contribution of demographic traits to the population growth rate. Ecology 81:642-653

Schiavini A, Yorio P, Gandini P, Rey AR, Boersma D (2005) Los pingüinos de las costas argentinas: estado poblacional y conservación. Hornero 20:5-23

Scolaro JA, Wilson RP, Laurenti S, Kierspel M, Gallelli H, Upton JA (1999) Feeding preferences of the Magellanic penguin over its breeding range in Argentina. Waterbirds 22:104-110 
Stokes DL, Boersma PD, Davis LS (1998) Satellite tracking of Magellanic penguin migration. Condor 100:376-381

Subsecretaría de Pesca y Acuicultura (2007) Pesquerías de calamar y langostino: situación actual. Secretaría de Agricultura, Ganadería, Pesca y Alimentos de la República Argentina, Buenos Aires

Sullivan BJ, Reid TA, Bugoni L (2006) Seabird mortality on factory trawlers in the Falkland Islands and beyond. Biol Conserv 131:495-504

Svagelj WS, Fernández GJ, Mermoz ME (2009) Effects of nest-site characteristics and parental activity on cowbird parasitism and nest predation in brown-and-yellow marshbirds. J Field Ornithol 80:9-18

Warham J (1996) The behaviour, population biology and physiology of the petrels. Harcourt Brace, San Diego, CA

Watkins BP, Petersen SL, Ryan PG (2008) Interactions between seabirds and deep water hake-trawl gear: an assessment of impacts in South African waters. Anim Conserv 11:247-254

Weimerskirch H, Capdeville D, Duhamel G (2000) Factors affecting the number and mortality of seabirds attending trawlers and long-liners in the Kerguelen area. Polar Biol 23:236-249

Wickliffe LC, Jodice PGR (2010) Seabird attendance at

Editorial responsibility: Hans Heinrich Janssen,

Oldendorf/Luhe, Germany shrimp trawlers in nearshore waters of South Carolina. Mar Ornithol 38:31-39

Yorio P (2009) Marine protected areas, spatial scales, and governance: implications for the conservation of breeding seabirds. Conserv Lett 2:171-178

Yorio P, Caille G (1999) Seabird interactions with coastal fisheries in Northern Patagonia: use of discards and incidental captures in nets. Waterbirds 22:207-216

Yorio P, Frere E, Gandini P, Harris G (1998) Atlas de la distribución reproductiva de aves marinas en el litoral patagónico Argentino. Plan de Manejo Integrado de la Zona Costera Patagónica. Fundación Patagonia Natural y Wildlife Conservation Society. Instituto Salesiano de Artes Gráficas, Buenos Aires

Yorio P, García-Borboroglu P, Potti J, Moreno J (2001) Breeding biology of Magellanic penguins Spheniscus magellanicus at Golfo San Jorge, Patagonia, Argentina. Mar Ornithol 29:75-79

Yorio P, Bertellotti M, Borboroglu PG (2005) Estado poblacional y de conservación de gaviotas que reproducen en el litoral Argentino. Hornero 20:53-74

Yorio P, Copello S, Kuba L, Gosztonyi AE, Quintana F (2010) Diet of imperial cormorants Phalacrocorax atriceps breeding at central Patagonia, Argentina. Waterbirds 33:70-78

Submitted: November 2, 2009; Accepted: March 24, 2011 Proofs received from author(s): May 30, 2011 